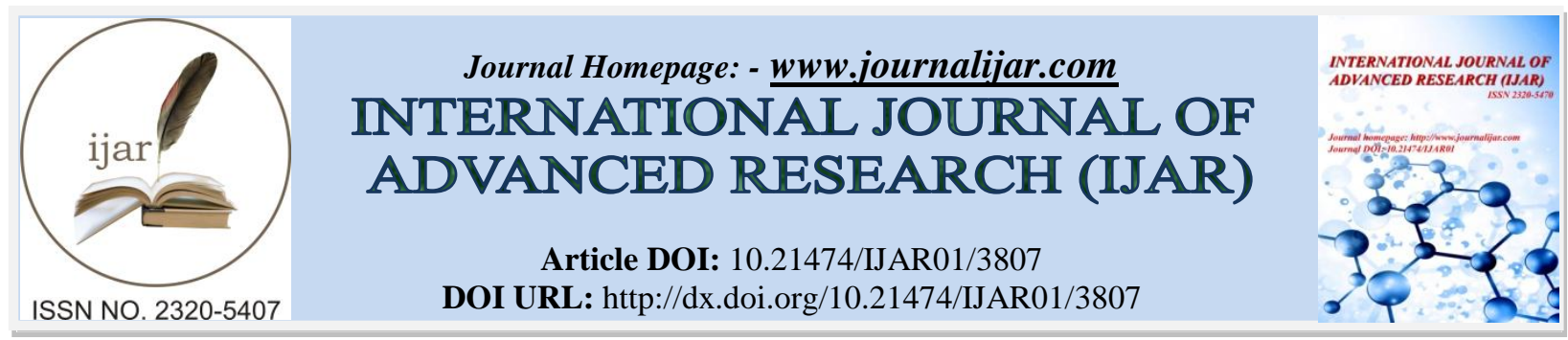

RESEARCH ARTICLE

\title{
GREEK-LATIN AND ENGLISH-AMERICAN LEXICAL BORROWINGS AND THEIR INFLUENCE ON CONTAMINATION OF THE FRENCH LANGUAGE
}

Safarova Umida Aliaskarovna

Samarkand State Institute of Foreign Languages, PhD, Senior scientific researcher

\section{Manuscript Info}

Manuscript History

Received: 05 February 2017

Final Accepted: 14 March 2017

Published: April 2017

Key words:-

language system, contamination, formation, syntagma, word-merging,

lexical, borrowing, Greek, Latin,

English, American, French, assimilation.

\section{Abstract}

The author demonstrates the peculiarities of lexical borrowings formed by the method of contamination and notes that they belong to the category of direct loans, which are the most impervious to the action of the natural tendency to find a name to a borrowed concept or object, that is expressed through linguistic means of the mother tongue and presence in contacting languages of their common international vocabulary layer, for example borrowings of similar Greek-Latin origin, that are involved in the process of contamination of words.

Copy Right, IJAR, 2017,. All rights reserved.

\section{Methods and Materials:-}

Methodological ground of the present investigation covers Greek-Latin and Anglo-American words borrowed into the French language; theoretical issues in the aspect of investigation of borrowings. The main issues among them that became necessary materials for research are scientific works by Budagov R., Lapshina M. N., Panyushkin V. V., Stepanov Yu., Stepanova A. N., Darmesteter A. and Guilbert P. The following methods were used in investigation: descriptive method, componential analysis, comparative method, method of lexical identification, method of classification and other linguistic methods.

\section{Results and Discussion:-}

French - is a language of mainly analytical system in which personalized attributive constructions generally correspond to the progressive sequence of the components "defined+ defining" which has developed after disintegration of Latin system of declination and establishment of a syntactic order between the members of a syntagma. However the language system of French contains some elements of a synthetism, in particular, in the sphere of vocabulary, formed on a way of word compounding and word-merging.

I. The synthetic type of compound words in French was created in the XVIII century on the borrowed Greek model. Till this period Greek-Latin composites made a layer of direct loans.

Revival of Greek-Latin composition, its conscious use for needs of the scientific and technical nomination is explained by a potential which it fully owns as an effective way of expression of several ideas in one word, which could be clear to a wide range of scientists, from where its appellation "composition savante" - "a book, scientific formation" comes. 
And, in composites not only the Greek, but also Greek with Latin elements can be connected, and later hybrid addition - connection of an element of a Greek-Latin origin with primordially French has gained prevalence in French.

Among "fancy" formations on "hybrid composition" A. Darmsteter gives examples of words like pha-lanstère = phalange+monastère, familistère $=$ famille + monastère which are qualified by us as properly contaminated words ${ }^{1}$.

At the same time it is characteristic that creation of contaminated compositions is made not according to etymological motivation any more, but according to specific functional model in the certain semantic field. There arises a paradigmatic formation, "processus de reproduction parimitation".

It must be kept in mind that in English along with a book type of composition lexemes of full-meaning are connected in a syntagma on the "defining+defined" model, and in French such arrangement of components exists only at Greek-Latin or hybrid composition.

At a word-merging compound lexical units, similar to Greek-Latin composition, are also created. This situation is right for both languages as a part of the first components of contaminated words have the final syllable, which is ending on - o - that makes one of relevant signs of properly Greek-Latin compositions along with other signs - an order: sequences of components, subordinative relations between them and others.

Involvement of a word-merging in process as the first contaminated word of Greek-Latin word-formative forms, ending on - o - also favors to perception of this subtype of word-merging as the process of imitation of Greek-Latin composition. It isn't convincing to base the thesis about borrowing the way of word compounding from English only on the assumption of an order of arrangement of the contaminated words components.

Other type of the French contaminated words is based on the syntactical principle, keeping that type of the syntactic relations, which corresponds to a progressive sequence of components in a syntagma - "defined + defining" ${ }^{2}$. Like compound words, which sometimes are functionally correlated to some extent to phrases, sometimes contaminated words can without transformation on an arrangement of components coincide with phrases.

Proceeding from coincidence of components arrangement in the contaminated word with an arrangement of elements in the phrase, we allocate the syntagmatic type of the French word-merging: banalitaire = banalité+militaire, ennuiversel $=$ ennui+universel, instamatic $=$ instantané+automatique, intellectronique $=$ intellect+électronique, nickinox=nickel+inoxidable.

The small group of syntagmatic contaminated educations is represented by personalized-binary designs, which second member is functionally a definition of the first noun, for example: Pistolux=pistolet+lux, Postéclair $=$ poste+éclair, Pristandard=prix+standard.

II. Centuries-old historical contacts, a community of social, economic and cultural life, geographical proximity of England and France, and also other external factors significantly influence the process of language interaction. Since 11th century the Norman dialect of French was the main source of replenishment of lexicon of English. According to academician Yu. S. Stepanov about 55 percent of English words are naturalized from French or Latin languages through French ${ }^{3}$.

In the new edition, titled "The dictionary of modern words", P. Gilbert included more than 320 anglicisms ${ }^{4}$. The majority among the contaminated words of Anglo-American borrowing is constituted by special lexicon - alltechnical, highly specialized terms, for example: bionique=biologie+électronique, cartrivision =

\footnotetext{
${ }^{1}$ Darmesteter A. De la création actuelle de mots nouveaux dans la langue francaise et des lois qui la régissent. P.: Vieweg, 1877.

${ }^{2}$ Panyushkin V. V. Semantics of the new formations, created by a way of a contamination. - Moscow, 1993. - Ch. I. $-116 \mathrm{p}$.

${ }^{3}$ Stepanov Yu. S. French stylistics.' - Moscow: Higher school, 1976. - 365 p.

${ }^{4}$ Guilbert P. Dictionnaire des mots nouveaux. - Paris, 1971. P. 449, 487, 515.
} 
cartridge+télévision, hélibarge $=$ hélicoptère+barge, robotique $=$ robot+automatique/informatique, telex=teleprinter+exchange, turbocoptère =turb(ine)+hélicoptère, vertiport=vertical+airport.

English-Americanisms meet also in the field of trade advertizing for designation of trademarks and names of products: permalloy $=$ perméable+alloy, mosamétal=mosaique+métal, aquatel=aqua+hôtel, in social and political terminology: Reaganomie=Reagan+économie, Reagalitique $=$ Reagan + politique, stagflation $=$ stagnation+inflation, in colloquial, colloquial lexicon; télébrité =télévision+célébrité, monokini = mono+bikini.

The tendency to form "hybrid" word compoundings on the basis of the English words, speaks about extent of penetration of anglicisms into French at the level of a word-merging, for example: céphalo-Bill>Buffalo-Bill, surpatte $>$ surprise+party, SHOE'SURshoes+chaussure, eggzistence=egg+existence, glamoureuse = glamour+amoureuse.

The known term fran-glais=français+anglais "frenglish" language, i.e. "modern French, contaminated by the excessive number of English loans ", the Anglomania which has taken today the anglodémie form = anglomanie+endémie where endémie - "a special disease, which is constant or appearing in any area during certain periods" became reflection of this tendency ${ }^{5}$.

Borrowing, as linguistic process of replenishment of lexical structure of language is complicated by existence of a large number of words in two languages, which have formal identity and partial semantic coincidence.

In the consequence of this fact there appear difficulties to find out the origin of this or that term. There are no sufficient reasons to establish cause and effect dependence between the country - the place of emergence of technical innovations, and natural ability of language of this country to express technical concepts.

So, the term altiport $=$ altitude+aéroport has appeared for the first time in France.

Sometimes borrowing the word is inevitable, when in language-recipient there is no equivalent for designation of the concept, which already has the name.

Lexical loans are connected with many extralinguistic factors and only basing on a dictionary remarks, carrying out a special research of history of creation of the separate word and, in a sort, proceeding from a contextual situation, it is possible to establish the genesis of this or that word compound with bigger or smaller reliability.

In the process of borrowing the contaminated words, they can formally modify, being exposed to partial or full phonetic and spelling adaptation.

Graphic assimilation is facilitated by using close alphabets in French and English languages.

Phonetic assimilation is followed by removing the stress on the final syllable, morphological assimilation, as a rule, consists in replacement of final elements of the borrowed word by its likening to the French words, for example: : Beagalitics- Beagalitique, avionics- avionique, deformeter-déformomètre, anglodozer - angle dozeur, stabistor stabisteur.

Owing to phonetic-morphological assimilation Anglo-American contaminated words do not represent any separate allogenny group, though special type of loans - not assimilated forms, occur among them, for example: Chunnel = Channel+tunnel, solion $=$ solution+ion, cartrivision $=$ cartridge + télévision, gazohol=gazoline+alcohol, permalloy $=$ permeable + alloy.

The feature of the borrowed lexicon, formed on a way of a contamination, is that it belongs to the category of direct loans which are most impenetrable to the action of a natural tendency to find the name, expressed by linguistic means of the native language to the borrowed conception or a subject.

\footnotetext{
${ }^{5}$ Budagov R. A. Introduction to science about language. $2^{\text {nd }}$ edition - Moscow, 1965. $-490 \mathrm{p}$.
} 


\section{Conclusion:-}

1. The existence of international layer of lexicon, general for them, a similar Greek-Latin origin of the words, involved in contamination process certainly promote the process of borrowing contaminated words from English.

2. The proximity of a word-merging method in the analyzed languages is shown, first, in emergence of new formations in French on the basis of English Americanisms: anglodozer-tournadozer; motel-Eurôtel, Equip'hôtel, batotel; newzine - fanzine; electrocution - hydrocution; secondly, availability of the general repeating fragments - components of words: alti(tude), (auto) of bus, (bull) of dozer, (électr) of onique, héli(coptère), (h) of otel, pétro(le), (télé) of visionetc. Compare: helicab, helimail - héliport, hélisurfâce; thirdly, in similarity of formal models of a word compound.

3. Studying the problems of the Anglo-French interlingual interaction, it is necessary to pay attention to the assumption stated by some French linguists about the borrowed character of a word compound method. This hypothesis is based not only on a large number of borrowed Anglo-American contaminated words, where the reasons of extralinguistic property can serve as an explanation for that.

4. In modern French the tendency to formation of the difficult personalized units created on the "defining+defined" model has amplified what the first A. Darmsteter has paid attention to. This thesis has been picked up by L. Guilbert, P. Giro, A. Gooss, L. Derua, Ge. Dubois, O. Sovazho and others. This syntagmatic model, which is typical for English language, gains prevalence among the French new formations by the principle of a word-merging.

5. A. Darmsteter spoke about the emergence of the first compound words in French language reproducing through the English model, an ellipsis of pretexts, as about the passing phenomenon partly explained as tribute to fashion $^{6}$. The appeal of linguists to the problems of language contacts, the language unions, the solution of these problems in comparative and typological researches is a characteristic feature of modern linguistics.

\footnotetext{
${ }^{6}$ Darmesteter A. La vie des mots étudiée dans leurs significations. - P.: Delagrave, 1886.
} 